\title{
The IPNV carrier state and demonstration of vertical transmission in experimentally infected brook trout
}

\author{
Linda M. Bootland, Peter Dobos, Roselynn M. W. Stevenson* \\ Department of Microbiology, College of Biological Sciences, University of Guelph, Guelph, Ontario, Canada N1G 2 W1
}

\begin{abstract}
Intraperitoneal injection of virulent infectious pancreatic necrosis virus (IPNV) into yearling brook trout Salvelinus fontinalis induced an asymptomatic, chronic virus infection that persisted for at least $76 \mathrm{wk}$ post-injection (wpi) in spite of the production of a strong humoral immune response. At 8 wpi, $100 \%$ of the fish in one of the injected groups were IPNV carriers, as determined by organ and feces sampling. At 76 wpi, $95 \%$ of the fish remained IPNV carriers. Vertical transmission of IPNV to progeny occurred, but the fry mortality rate, the prevalence of IPNV-infection, and mean IPNV titres were low. Hence, vertical transmission is not recommended as a criterion for evaluating the efficacy of broodstock immunization. The IPNV carrier state in yearlings that had survived a direct immersion in IPNV as fry was equivalent to that induced in yearlings by injection, in terms of the number of IPNV-infected organs per fish and the prevalence and titre of IPNV in the visceral organs when fish were sampled at 73 and 76 wpi, respectively. However, the injected yearlings mounted a stronger humoral immune response to IPNV that the fish surviving the direct immersion. Since the IPNV carrier state induced by injection was nearly indistinguishable from the natural IPNV carrier state, intraperitoneal injection can be used as a challenge protocol for broodstock immunization trials.
\end{abstract}

\section{INTRODUCTION}

In young salmonids, infectious pancreatic necrosis virus (IPNV) can cause an acute disease episode with high mortalities, followed by a life-long, chronic infection in the survivors (Dorson 1982). IPNV carriers are asymptomatic, persistently infected fish that have virus in many visceral organs. Although the carrier fish mount a humoral immune response, they periodically shed infectious IPNV in the feces and reproductive products (Hill 1982) and can vertically transmit the virus to their progeny (Ahne \& Negele 1985, Dorson \& Torchy 1985). Rainbow trout Salmo gairdneri adults, whether experimentally infected by intraperitoneal injection of IPNV (Reno et al. 1978, Ahne \& Thomsen 1986) or naturally infected (Yamamoto 1974, 1975a, Mangunwiryo \& Agius 1988), have an unpredictable persistence of the IPNV carrier state, ranging from 10 mo to over $2 \mathrm{yr}$. The natural IPNV carrier state in brook trout Salvelinus fontinalis adults has been well

\footnotetext{
- Addressee for correspondence
}

characterized with respect to the prevalence and titre of the virus in the visceral organs, feces, and reproductive products and with respect to the humoral immune response (Wolf et al. 1968, Yamamoto 1974, Yamamoto \& Kilistoff 1979).

Immunizing broodstock to prevent the establishment of the IPNV carrier state is one potential approach to controlling IPN disease in fry, by preventing vertical transmission of the virus. Sano et al. (1981) found that if rainbow trout broodstock, experimentally immunized with inactivated IPNV, had an IPNV-neutralizing antibody titre of greater than $10^{3} \mathrm{ND}_{50}$, then virus could not be re-isolated from the kidney or gonad 1 to $2 \mathrm{wk}$ after an intravenous challenge with live virus. However, in Sano's study, other organs and feces were not tested for IPNV-infection, nor was it determined if a long-term IPNV carrier state existed. As the natural carrier state occurs more frequently and persists for a longer time in brook trout than in rainbow trout (Yamamoto 1974, 1975b, Reno 1976), brook trout is the species of choice for studies of adult IPNV immunization.

To accurately assess the efficacy of broodstock immunization, a reliable, reproducible IPNV challenge 
protocol is essential. Because adult salmonids do not suffer IPNV-induced mortalities or show signs of disease (Hill 1982), it is necessary to have a challenge protocol that induces an IPNV-carrier state in unimmunized fish. Ideally, the experimentally-induced carrier state should closely resemble the natural carrier state in the prevalence and titre of virus in the feces and reproductive products, and the carrier fish should vertically transmit the virus. Intraperitoneal injection is the method of choice for infecting adult fish as, unlike the more natural oral or direct immersion routes of infection, injection allows the administration of a uniform virus dose per fish and does not require large amounts of virus.

The IPNV carrier state induced in adult brook trout by injection of virulent virus has not been characterized in sufficient detail to conclude that the experimental and natural carrier states are equivalent. In a shortterm study, Swanson (1981) was able to re-isolate IPNV from the kidney and gastrointestinal tract of adult brook trout $10 \mathrm{~d}$ after an intraperitoneal injection of the virus. In a longer study, Wolf \& Quimby (1969) could not re-isolate IPNV from the 2 adult brook trout tested at 10 mo post-injection, and hence suggested that intraperitoneal injection of IPNV induced only a transient carrier state.

The objective of this study was to assess intraperitoneal injection of virulent IPNV into adult brook trout as a potential IPNV challenge protocol for use in future IPNV immunization trials. The short-term results of this study (Bootland et al. 1986a) showed that adult trout underwent a transient, $12 \mathrm{wk}$ viraemia after an injection of virulent virus, and the fish shed IPNV in feces for at least $27 \mathrm{wk}$ post-injection (wpi) at titres equivalent to those found in the feces of naturallyinfected brook trout. In this communication, the longterm experimentally-induced carrier state and the humoral immune response of adult brook trout were monitored for 76 wpi. These results were compared with those of yearling survivors of an IPN-outbreak induced by immersion in virus as fry, in order to determine if experimental infection of adults induces a carrier state equivalent to the natural carrier state. The use of vertical transmission as a means of assessing the efficacy of future IPNV broodstock vaccines was also evaluated.

\section{MATERIALS AND METHODS}

Virus growth and purification. The virulent Quebec IPNV isolate (VR299 serotype) used in this study was isolated from a natural IPN epizootic in brook trout Salvelinus fontinalis at a Quebec hatchery, and was kindly provided by Dr M. A. S. Y. Elazhary, University of Montreal, St. Hyacinthe, Quebec, Canada. For virus growth, CHSE-214 cell monolayers were cultured at $18^{\circ} \mathrm{C}$ in glass roller bottles containing Eagles's minimal essential medium with Earle's salts (GIBCO) supplemented with $200 \mathrm{IU} \mathrm{ml} \mathrm{m}^{-1}$ penicillin, $200 \mu \mathrm{g} \mathrm{ml} \mathrm{m}^{-1}$ streptomycin, and $6 \%$ fetal bovine serum (cMEM). IPNV was added at a low multiplicity of infection and virus was harvested when a complete cytopathic effect (CPE) was evident.

IPNV (cell culture passage 4) was concentrated by polyethylene glycol- $\mathrm{NaCl}$ precipitation, purified by Freon extraction and isopycnic $\mathrm{CsCl}$ gradient centrifugation as described by Chang et al. (1978) and Dobos et al. (1979), and then stored at $-70^{\circ} \mathrm{C}$. Infectious virus titre was measured by plaque assays using $14 \mathrm{mM}$ HEPES buffer in the overlay as described by Wolf \& Quimby (1973).

Fish maintenance. IPNV-free yearling brook trout (225 \pm 7 g) were purchased from Van Aqua Co., Burford, Ontario, Canada. Fish were divided into 4 groups of 20 fish, with each group having approximately equal numbers of males and females. Each group was acclimated for $4 \mathrm{mo}$ and maintained in separate $550 \mathrm{l}$ fibreglass tanks supplied with flowing, aerated well water, temperature-controlled $\left(10 \pm 1{ }^{\circ} \mathrm{C}\right)$ by water chiller units (Frigid Units Inc., Toledo, Ohio, USA). The room lighting was controlled to correspond to the natural photoperiod. Adult fish were fed until satiated once per day with dry trout pellets (Martin Feed Mills Ltd., Elmira, Ontario).

Fish maintenance and experimental procedures were in accordance with the principles of the Canadian Council on Animal Care. Prior to any experimental procedure, fish were individually anaesthetized in $100 \mathrm{ppm}$ MS222 (tricane methanesulfonate) at 15 to $17^{\circ} \mathrm{C}$ until loss of the righting reflex. After virus infection of fish, effluent water was disinfected by a minimum $2 \mathrm{~h}$ exposure time to a final concentration of $10 \mathrm{ppm}$ sodium hypochlorite.

Infection and sampling of fish. The fish groups and the time-table of sampling of serum, feces, reproductive products, and organs are summarized in the flowchart (Fig. 1). At each sampling time, fish were measured for wet weight $(\mathrm{g})$ and standard length $(\mathrm{mm})$. Three weeks prior to injection, fish were marked for individual identification using silver nitrate pencils (Bootland et al. 1986b), then sampled for feces and serum. At each sample time, $10 \%$ of the total blood volume, $V$, was removed from each fish, as calculated by the equation of Houston \& DeWilde (1969):

$$
\mathrm{V}(\mathrm{ml})=0.0055 \times \text { fish weight }(\mathrm{g})
$$

Two groups of 20 fish, designated Groups I and II, were injected intraperitoneally with purified Quebec IPNV diluted in CMEM $\left(1.5 \times 10^{5} \mathrm{pfu}^{-1}\right.$ body weight). Ten control fish in each of the 2 remaining groups (III 


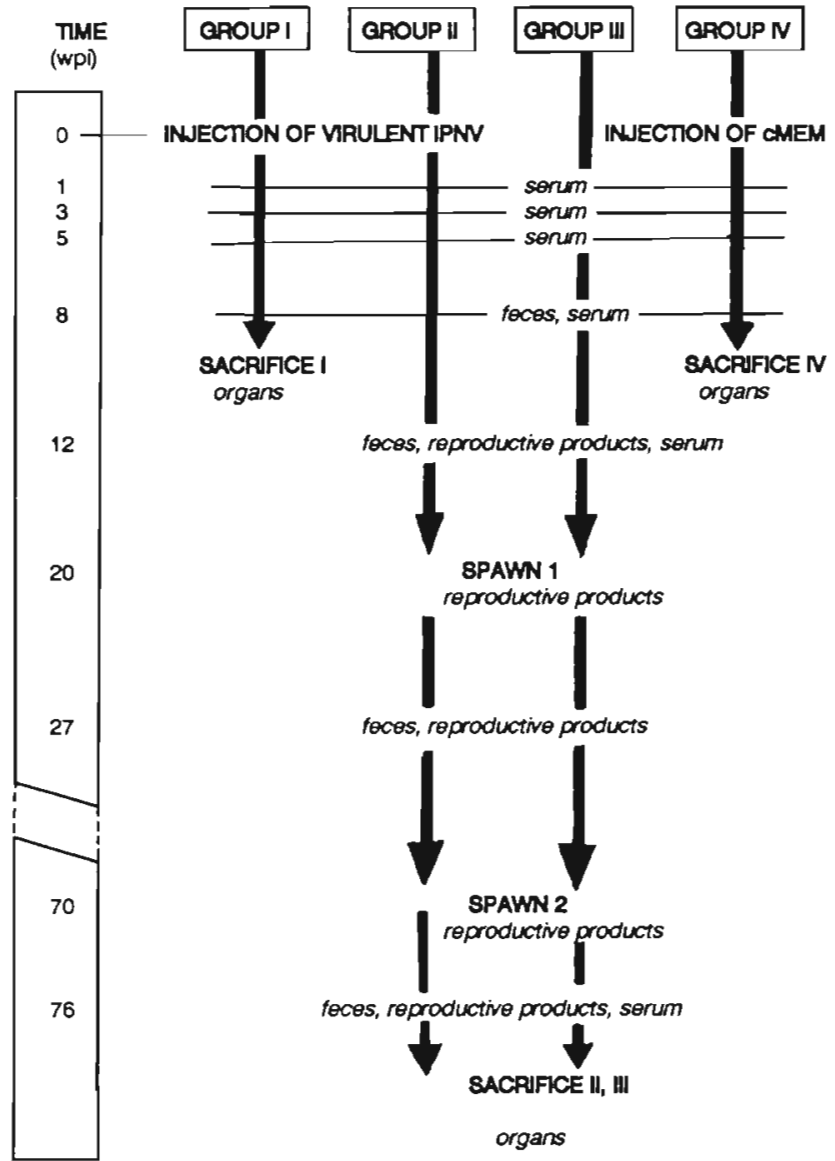

Fig. 1. Time-course schema of the experimental procedures and samples taken from 4 groups of brook trout given an intraperitoneal injection of virulent IPNV or cMEM. Feces, reproductive products, and organs were tested for IPNV. Serum was assayed for neutralizing antibodies. wpi: weeks post-injection

and IV) were similarly injected with equivalent volumes of cMEM. The remaining 10 fish in Groups III and IV served as uninjected controls. The mean volume injected per fish was $0.5 \mathrm{ml}$.

Fish in Groups I and IV were sacrificed at $8 \mathrm{wpi}$, and those in Groups II and III at 76 wpi. The spleen, posterior kidney, anterior kidney, pyloric caeca-pancreas, liver, gonad, and intestine were aseptically removed from each fish and assayed for IPNV.

Spawning and progeny sampling. At $20 \mathrm{wpi}, 9$ mating crosses were made using Group II (IPNVinjected) and Group III (control) fish as follows: 2 crosses between control fish, 3 crosses in which the male was infected, 3 crosses with infected females, and 1 cross in which both parents were infected. For the second spawning, at $70 \mathrm{wpi}$, only 1 cross for each possible combination was made. Fertilized eggs from each cross were placed in separate plastic egg-incubation units supplied with flowing 7 to $9^{\circ} \mathrm{C}$ well water. Dead eggs were removed from the units daily, and samples of live and dead eggs were tested for IPNV infection from 15 to $49 \mathrm{~d}$ post-fertilization. Fry were monitored for signs of IPN, and daily mortalities from $8 \mathrm{~d}$ post-hatch (dph) to $122 \mathrm{dph}$ were examined for IPNV infection. At $7,11,14$, and 16 mo posthatch, pooled organ samples from individual progeny of the 20 wpi spawning were tested for IPNV.

Yearling survivors. Brook trout fry, obtained from Hills Lake Fish Culture Station, Ontario Ministry of Natural Resources, were exposed to virulent Quebec IPNV using the protocol of McAllister \& Owens (1986). At 8.5 wk post-hatching (fry weight $0.151 \pm 0.004 \mathrm{~g}$ ), a group of 90 fish was directly immersed for $5 \mathrm{~h}$ in 31 of $10^{\circ} \mathrm{C}$ aerated water containing IPNV $\left(1.38 \times 10^{6} \mathrm{pfu}\right.$ $\mathrm{ml}^{-1}$, cell culture passage 3). A control group of 90 fish was similarly immersed in cMEM only. After $25 \mathrm{~d}$, the cumulative percent mortality (C\%M) was $49 \%$ for fry exposed to IPNV, compared with $3 \%$ in the control group. IPNV was isolated from all (43/43) IPNVexposed fry mortalities, but not from the control fish $(0 /$ 3). Surviving fry were reared for $73 \mathrm{wk}$ post-exposure, then feces, serum, and 6 organs (spleen, posterior kidney, liver, pyloric caeca-pancreas, gonad, and intestine) from 10 of the adult fish in each group were tested for IPNV.

Virological examination. All samples were kept at $4{ }^{\circ} \mathrm{C}$ and prepared for virological examination within $24 \mathrm{~h}$ of collection. Whole fry and organ samples, feces, eggs and ovarian fluid, and milt were diluted in CMEM to a final concentration ( $w / v$ ) of $1 / 50,1 / 20,1 / 5$ and $1 / 2$, respectively, homogenized with a Stomacher (Seward Laboratory, London, England), and centrifuged (1200 $\times g, 15 \mathrm{~min}, 4^{\circ} \mathrm{C}$ ). Supernatants were passed through $0.45 \mu \mathrm{m}$ filters and stored at $4^{\circ} \mathrm{C}$ for tests done within $15 \mathrm{~d}$; otherwise they were stored at $-20^{\circ} \mathrm{C}$. This procedure was followed because preliminary experiments indicated that virus infectivity titres only started to decrease after $15 \mathrm{~d}$ at $4{ }^{\circ} \mathrm{C}$, whereas a single freezing and thawing reduced the titre by 1 log (data not shown).

The IPNV titre in feces, organs, reproductive products, and fertilized eggs was determined by serial dilution endpoint assays, in which 5-fold dilutions of samples were incubated with CHSE- 214 cells at $18^{\circ} \mathrm{C}$. Cells were examined for CPE for $14 \mathrm{~d}$, then all samples were blind-passaged. Staphylococcal coagglutination (Kimura et al. 1984) was used to confirm that CPE observed in passage 1 and 2 was caused by IPNV. The IPNV titre in fish samples was calculated using the Spearman-Karber formula (Wardlaw 1985). Fry samples were tested for IPNV-infection as above, except only the initial $1 / 50$ and $1 / 100$ sample dilutions were used. The limit of IPNV detection was $2.70 \log$ TCID $_{50}$ $\mathrm{g}^{-1}$ for fry and organs; 2.30 for feces; 1.30 for milt, and 1.70 for eggs. 
Serum neutralization test. Blood was allowed to clot overnight at $4^{\circ} \mathrm{C}$, and the resulting serum stored at $-20^{\circ} \mathrm{C}$ until assayed. IPNV-neutralizing antibodies were detected and titrated by serum neutralization tests using doubling dilutions of unheated serum, and a constant virus dose of 100 to 200 pfu. After incubation at $18^{\circ} \mathrm{C}$ for $7 \mathrm{~d}$, RTG-2 cells were examined for CPE. IPNV-neutralizing antibody titres were calculated using the Spearman-Karber formula. The minimum antibody titre detectable was $0.85 \log \mathrm{ND}_{50}$ per $0.05 \mathrm{ml}$ serum.

Statistical analysis. Analysis of variance (ANOVA) and Duncan's multiple range test were used to identify significant differences in the IPNV-titres of the feces over time and in the organs within each group. T-tests were used to compare organ virus titres at 8 and $76 \mathrm{wpi}$. The $\chi^{2}$-test was used to test for differences between and within groups for the prevalence of IPNV infection. Simple linear regression analysis and t-tests were used on logarithmically ( $\log _{10}$ ) transformed adult fish lengths and weights to monitor fish growth. All tests used a significance level of $5 \%$.

\section{RESULTS}

\section{Non-lethal detection of IPNV carriers}

At the time of injection, all 4 groups were equivalent in mean wet weight $(333 \pm 12 \mathrm{~g}$ to $352 \pm 12 \mathrm{~g})$. During the experiment, IPNV infection did not impair growth of the fish, as control and IPNV-injected fish were not significantly different in mean wet weight at $8 \mathrm{wpi}$ (Group I: $405.7 \pm 12.8 \mathrm{~g}$; Group IV: $446.8 \pm 22.5 \mathrm{~g}$ ) or at $76 \mathrm{wpi}$ (Group II: $1468.4 \pm 66.5 \mathrm{~g}$; Group III: 1538.3 $\pm 88.4 \mathrm{~g}$ ). Between injection and 8 wpi, there was a single, non-specific mortality in each of Groups I, III, and IV and none in Group II. No injected fish showed external signs of IPN. IPNV was not detected in any

Table 1. Salvelinus fontinalis. Prevalence and mean titres of IPNV in the feces of Group II IPNV-injected brook trout

\begin{tabular}{|c|c|c|c|}
\hline $\begin{array}{l}\text { Time } \\
\text { (wpi) }^{\text {a }}\end{array}$ & $\begin{array}{c}\text { Total } \\
\text { no. fish }\end{array}$ & $\begin{array}{l}\text { Prevalence of } \\
\text { IPNV-infected } \\
\text { feces }(\%)\end{array}$ & $\begin{array}{c}\text { Mean } \\
\text { IPNV titre } \\
\left(\log \mathrm{TCID}_{50} \mathrm{~g}^{-1}\right. \\
\pm \mathrm{SE})\end{array}$ \\
\hline-3 & 20 & 0 & - \\
\hline 8 & 15 & 73 & $3.45 \pm 0.21$ \\
\hline 12 & 10 & 100 & $3.89 \pm 0.26$ \\
\hline 27 & 19 & 63 & $3.72 \pm 0.17$ \\
\hline 76 & 10 & 40 & $2.33 \pm 0.37$ \\
\hline \multicolumn{4}{|c|}{ api: weeks post-injection } \\
\hline
\end{tabular}

samples from the control groups, nor in fecal samples taken prior to IPNV-injection.

At $8 \mathrm{wpi}, 73 \%$ of the Group II fish were shedding IPNV in their feces at a mean IPNV titre of $3.45 \pm 0.21$ $\log \mathrm{TCID}_{50} \mathrm{~g}^{-1}$ (Table 1). Similar results were obtained for Group I fish at 8 wpi $\left(57 \%, 3.89 \pm 0.53 \log\right.$ TCID $_{50}$ $\mathrm{g}^{-1}$ ), which were sacrificed after this sampling. Between 8 and 27 wpi, the prevalence of fecal IPNV shedders and mean fecal IPNV titres in Group II IPNVinjected fish did not significantly change, but over a longer time, 27 to $76 \mathrm{wpi}$, there was a significant decrease in both the number of fecal shedders and in the mean fecal IPNV titre (Table 1).

Egg-ovarian fluid samples obtained from Group II females over the 2 spawning seasons rarely contained IPNV, and then only at low mean IPNV titres (Table 2). However, many of the male fish in this group yielded IPNV-infected milt samples during both spawning seasons but the mean IPNV titre in the milt was low except for one sample at 20 wpi (Table 2).

\section{Organ samples}

At $8 \mathrm{wpi}$, IPNV was isolated from at least 2 visceral organs in all of the Group I fish. At 76 wpi, 95\% (19/20) of the Group II fish still had IPNV in at least one organ. Although the percentage of IPNV carriers, defined as fish with at least one IPNV-infected organ, did not

Table 2. Salvelinus fontinalis. Infection of the reproductive products of IPNV-injected Group II brook trout over 2 successive spawning seasons

\begin{tabular}{|c|c|c|c|c|}
\hline \multirow[t]{2}{*}{$\begin{array}{c}\text { Time } \\
(w p i)^{\alpha}\end{array}$} & \multicolumn{2}{|c|}{ Milt } & \multicolumn{2}{|c|}{$\begin{array}{l}\text { Eggs and ovarian } \\
\text { fluids }\end{array}$} \\
\hline & $\begin{array}{c}\text { No. } \\
\text { infected/ } \\
\text { total } \\
\text { sampled }^{\text {b }}\end{array}$ & $\begin{array}{l}\text { Mean } \\
\text { IPNV titre } \\
\pm S E^{c}\end{array}$ & $\begin{array}{c}\text { No. } \\
\text { infected } \\
\text { total } \\
\text { sampled }\end{array}$ & $\begin{array}{l}\text { Mean } \\
\text { IPNV titre } \\
\quad \pm \mathrm{SE}\end{array}$ \\
\hline 12 & $4 / 9$ & $2.01 \pm 0.49$ & $\mathrm{NA}^{\mathrm{d}}$ & NA \\
\hline 20 & $1 / 5$ & 5.15 & $1 / 3$ & 2.05 \\
\hline 27 & $4 / 6$ & $1.74 \pm 0.26$ & $0 / 5$ & - \\
\hline 70 & $0 / 2$ & - & $0 / 2$ & - \\
\hline 76 & $4 / 5$ & $2.86 \pm 0.58$ & $0 / 5$ & - \\
\hline \multicolumn{5}{|c|}{$\begin{array}{l}\text { a wpi: weeks post-injection } \\
\text { b For Spawn } 1,11 \text { males and } 7 \text { females were sampled. Milt } \\
\text { samples were obtained from } 9 \text { of the males at only } 2 \text { of } 3 \\
\text { sampling times, with } 2 \text { males yielding milt at only one } \\
\text { sampling time. Egg-ovarian fluid samples from each. } \\
\text { female were obtained at either } 20 \text { or } 27 \text { wpi in Spawn } 1 \text {. } \\
\text { For Spawn } 2,7 \text { males and } 7 \text { females were sampled once } \\
\text { for reproductive products at either } 70 \text { or } 76 \mathrm{wpi}^{-} \\
\text {"Milt IPNV titres expressed as log TCID } \mathrm{ml}_{50} \text {; egg- } \\
\text { ovarian fluid IPNV titres expressed as log TCID } \text { TC }_{50}^{-1} \\
\text { d NA: samples not available }\end{array}$} \\
\hline
\end{tabular}




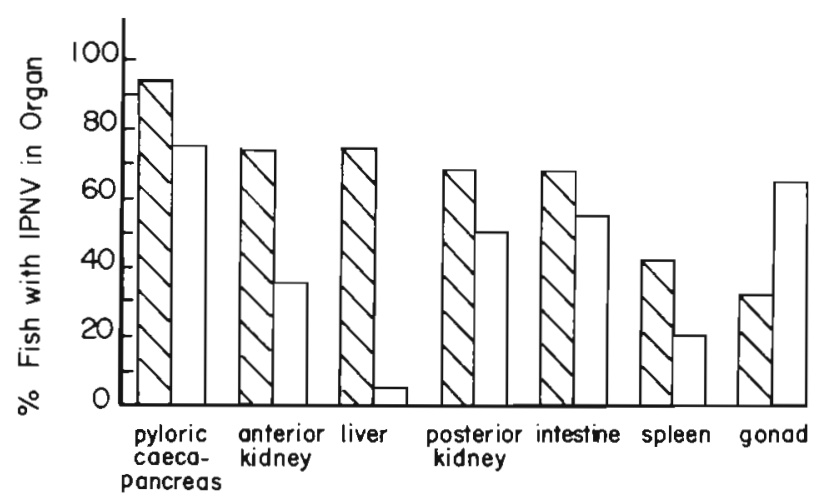

Fig. 2. Salvelinus fontinalis. Prevalence of IPNV infection in individual organs of adult brook trout infected by intraperitoneal injection. Fish were sampled at $8 \mathrm{wpi}$ (shaded bars, Group I) or at $76 \mathrm{wpi}$ (open bars, Group II). Sample size for all organs at 8 wpi was 19 , except for the gonads, where $\mathrm{n}=16$. At 76 wpi, $\mathrm{n}=20$

significantly diminish over time, there was a slight decrease in the total number of organs that were IPNVinfected in each fish. The number of fish with 4 or more infected organs at 8 wpi was $12 / 19$, compared with $8 /$ 20 at 76 wpi. IPNV was not detected from any organs of control fish.

At 8 wpi, IPNV was widely distributed in all the visceral organs, with the pyloric caeca-pancreas, anterior and posterior kidney, liver and intestine infected in at least $70 \%$ of the fish; the spleen and gonad were less commonly infected (Fig. 2). By 76 wpi, the prevalence of IPNV infection in the anterior kidney and liver had significantly decreased, but the increase seen in the gonad was not statistically significant (Fig. 2). At both 8 wpi and 76 wpi, the pyloric caecapancreas had the highest mean IPNV titre (Table 3). The mean IPNV titres of the pyloric caeca-pancreas, anterior and posterior kidney, liver and intestine at 76 wpi were slightly, but not significantly, decreased

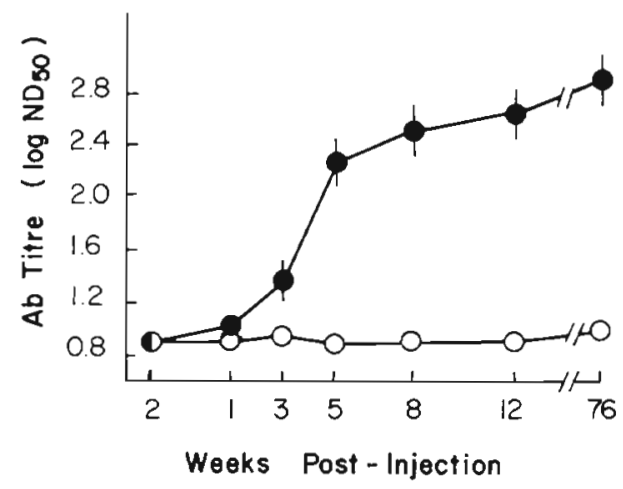

Fig. 3. Salvelinus fontinalis. Mean IPNV-neutralizing antibody titres elicited by intraperitoneal injection of yearling brook trout with virus. The IPNV-injected $(\bullet)$ and control $(0)$ groups each included 10 fish. Vertical lines indicate standard error of mean antibody titre

from those at 8 wpi. Only the gonad showed a significant increase in mean IPNV titre with time (Table 3).

\section{Humoral immune response}

The mean titres of neutralizing antibodies in the control fish (Group IV) did not exceed $0.99 \pm 0.08 \mathrm{log}$ $\mathrm{ND}_{50}$ (Fig. 3). Six of the control fish never had detectable neutralizing antibody titres, but the remaining fish had titres as high as $1.38 \log N D_{50}$ during the 76 wpi. Thus, antibody titres of $\leq 1.38 \log \mathrm{ND}_{50}$ were considered as background levels.

Injection of IPNV into Group II fish induced a humoral immune response in all of the 10 fish tested, with 5 of the fish having an antibody titre of $>1.38 \mathrm{log}$ $\mathrm{ND}_{50}$ by 3 wpi. From 3 to $5 \mathrm{wpi}$, antibody production was rapid, then continued, to increase slowly to a maximum titre at 76 wpi (Fig. 3). Antibody titres within

Table 3. Salvelinus fontinalis. Mean IPNV titres in individual organs of yearling brook trout after injection with IPNV

\begin{tabular}{|c|c|c|c|c|}
\hline \multirow{2}{*}{$\begin{array}{l}\text { Sampled at: } \\
\text { Organ }\end{array}$} & \multicolumn{2}{|c|}{$8 w \mathrm{wi}^{\mathrm{a}}$} & \multicolumn{2}{|c|}{76 wpi } \\
\hline & No. $t^{a}$ & Mean titre ${ }^{b}$ & No. + & Mean titre \\
\hline Pyloric caeca-pancreas & (18) & $4.56 \pm 0.23$ & (15) & $3.98 \pm 0.28$ \\
\hline Anterior kidney & (14) & $3.63 \pm 0.30$ & $(7)$ & $3.00 \pm 0.13$ \\
\hline Posterior kidney & (13) & $3.52 \pm 0.18$ & $(10)$ & $3.38 \pm 0.29$ \\
\hline Liver & (14) & $3.48 \pm 0.19$ & (1) & 3.35 \\
\hline Intestine & (13) & $3.31 \pm 0.31$ & (11) & $3.22 \pm 0.20$ \\
\hline Gonad & $(5)$ & $3.09 \pm 0.19^{\circ}$ & (13) & $3.67 \pm 0.20$ \\
\hline Spleen & (8) & $2.88 \pm 0.07$ & (4) & $3.21 \pm 0.51$ \\
\hline \multicolumn{5}{|c|}{$\begin{array}{l}\text { api: weeks post-infection } \\
\text { "Numbers represent numbers of each organ that were IPNV-infected. For all organs at } 8 \text { wpi the sample size was } 19 \text {, except } \\
\text { for gonads where only } 16 \text { fish were sampled. At } 76 \text { wpi, the sample size for all organs was } 20 \\
\text { "Mean IPNV titre is expressed as TCID } \text { TC }^{-1} \pm \text { SE } \\
\text { - Significant difference }(p<0.05) \text { between } 8 \text { and } 76 \text { wpi }\end{array}$} \\
\hline
\end{tabular}


a sampling time fluctuated up to $2.11 \log \mathrm{ND}_{50}$ between individual fish, indicating wide variability in the humoral immune rsponse of individuals.

\section{Vertical transmission}

IPNV was not detected in fertilized eggs from any of the 13 crosses made in the 2 spawning years. Fertilized eggs from 4 crosses in Spawn 1 (20 wpi) did not survive until hatching, but progeny were obtained from 2 crosses between uninfected parents, 2 crosses between infected males and uninfected females, and 1 cross between an infected male and female. For Spawn 2 (70 wpi), only progeny from the infected male-uninfecied temaie cross and controi crosses were obtained. Progeny resulting from crosses involving 1 or 2 IPNVinfected parents in both spawnings did not undergo an epizootic, had a low prevalence of IPNV-infection, and low virus titres. However, these progeny showed typical signs of IPN, such as exophthalmia, trailing fecal casts, and whirling swimming behaviour, from ca $29 \mathrm{dph}$ to $70 \mathrm{dph}$.

For Spawn 1, the milt of the infected males crossed with control females did not have detectable IPNV. Although IPNV was not isolated from the resulting progeny until $51 \mathrm{dph}$, low titres of IPNV were periodically isolated from a few progeny up to 16 mo posthatch (mph) (Table 4). For the infected male-female cross, IPNV was isolated from the egg-ovarian fluid IPNV $\left(2.70 \log \mathrm{TCID}_{50} \mathrm{~g}^{-1}\right)$ and at a high titre from the milt $\left(5.15 \log \mathrm{TCID}_{50} \mathrm{ml}^{-1}\right.$ ). Progeny from this cross did not have detectable levels of IPNV from 28 to $72 \mathrm{dph}$

Table 4. Salvelinus fontinalis. Detection of IPNV in progeny of crosses made between IPNV-injected males and control females in the first spawning season

\begin{tabular}{|c|c|c|c|}
\hline $\begin{array}{l}\text { Sampled } \\
\text { time } e^{a}\end{array}$ & $\begin{array}{c}\text { No. fish } \\
\text { tested }\end{array}$ & $\begin{array}{l}\text { No. IPNV } \\
\text { positive }\end{array}$ & $\begin{array}{l}\text { Mean IPNV titre } \\
(\log \text { TCID } 50 \\
\left.g^{-1} \pm S E\right)\end{array}$ \\
\hline \multicolumn{4}{|l|}{ Fry (dph) } \\
\hline $24-50$ & 90 & 0 & $-{ }^{b}$ \\
\hline 51 & 20 & 2 & $2.70 \pm 0$ \\
\hline $52-99$ & 55 & 0 & - \\
\hline 100 & 2 & 1 & 2.70 \\
\hline \multicolumn{4}{|c|}{ FingerLings (mph) } \\
\hline 7 & 16 & 0 & - \\
\hline 11 & 10 & 0 & - \\
\hline \multicolumn{4}{|c|}{ Yearlings (mph) } \\
\hline 14 & 25 & 1 & 2.70 \\
\hline 16 & 206 & 5 & $2.76 \pm 0.06$ \\
\hline \multicolumn{4}{|c|}{$\begin{array}{l}\text { a Sampling times indicated as days post-hatch (dph) or } \\
\text { months post-hatch (mph) } \\
\text { b-: IPNV not detected in fish samples }\end{array}$} \\
\hline
\end{tabular}

(69 fish tested) or when tested as fingerlings at 7 and $11 \mathrm{mph}$ (31 fish tested). However, at $16 \mathrm{mph}, 2$ of 60 progeny were IPNV-infected at a low virus titre $(2.70$ $\log$ TCID $_{50} \mathrm{~g}^{-1}$ ).

For Spawn 2, progeny of the infected male-uninfected female cross had a low mortality rate $(10 \%$ at $100 \mathrm{dph}$ ), equal to that of progeny from uninfected parents. Progeny had a low prevalence of IPNV infection $(124 / 1566$ fry, $8 \%)$ when measured from 49 to $119 \mathrm{dph}$, and a mean IPNV titre $\left(3.01 \pm 0.11 \log\right.$ TCID $_{50}$ $\mathrm{g}^{-1}$ ). IPNV was not isolated from the progeny of crosses made between uninfected parents in either spawning.

\section{Survivors of fry-infection}

When fish that had survived IPNV-infection as fry were sampled $173 \mathrm{wk}$ post-exposure, 9 of 10 fish were fecal IPNV shedders. The mean fecal IPNV titre $(3.00$ $\pm 0.28 \log \mathrm{TCID}_{50} \mathrm{~g}^{-1}$ ) was significantly different than that of the injected Group II yearling fish $(2.33 \pm 0.37$ $\log \mathrm{TCID}_{50} \mathrm{~g}^{-1}$ ). All 10 fish sampled at $73 \mathrm{wk}$ were IPNV carriers and they yielded 1 to 4 IPNV-infected organs per fish. The prevalence of IPNV infection and the mean IPNV titre in all visceral organs except the gonad and intestine (Table 5) were similar to those of the IPNV-injected yearlings sampled at $76 \mathrm{wpi}$ (Table 3).

IPNV-infection of fry did not subsequently affect fish growth, as there were no significant differences in mean wet weight between yearlings that had been immersed as fry in IPNV $(123.2 \pm 7.8 \mathrm{~g})$ or CMEM $(112.9 \pm 3.9 \mathrm{~g})$ when sampled $73 \mathrm{wk}$ later. Immersion of fry in IPNV elicited only a slight humoral immune response, as the mean neutralizing antibody titre was $1.81 \pm 0.20 \log \mathrm{ND}_{50} 73 \mathrm{wk}$ later.

Table 5. Salvelinus fontinalis. Prevalence of IPNV infection and mean IPNV titres in organs of yearling brook trout exposed to IPNV by direct immersion as fry. Fry exposed to IPNV were held for $73 \mathrm{wpi}$, then the organs from 10 fish were tested for IPNV infection

\begin{tabular}{|lcc|}
\hline Organ & $\begin{array}{c}\text { No. IPNV- } \\
\text { infected }\end{array}$ & $\begin{array}{c}\text { Mean IPNV titre } \\
\left(\log ^{-1} \text { TCID }_{50}\right. \\
g^{-1} \pm \text { SE) }\end{array}$ \\
\hline $\begin{array}{l}\text { Pyloric caeca-pancreas } \\
\text { Posterior kidney }\end{array}$ & 7 & $3.73 \pm 0.39$ \\
Liver & 5 & $3.29 \pm 0.16$ \\
Intestine & 5 & $2.80 \pm 0.05$ \\
Gonad & 8 & $4.06 \pm 0.31$ \\
Spleen & 0 & $2.74 \pm 0.02$ \\
a Number of organ samples ( $\mathrm{n}=10)$ & - \\
IPNV &
\end{tabular}




\section{DISCUSSION}

A single intraperitoneal injection of a high dose of virulent IPNV effectively induced a persistent IPNV carrier state in yearling brook trout. The carrier state in yearling fish appeared similar, regardless of whether fish had been given an IPNV injection as adults or had, as fry, survived an epizootic produced by direct immersion in a suspension of the virus. Both routes of IPNV exposure induced a persistent, chronic, asymptomatic infection in adults that lasted for at least $17 \mathrm{mo}$, as the fish had several IPNV-infected visceral organs and also shed virus in the feces. The carrier state resulting from either route of experimental infection was hence analogous to the carrier state described for brook trout naturally infected with IPNV (Yamamoto 1974, Reno 1976).

The prevalence of experimentally infected fish shedding IPNV in their feces and the fecal IPNV titres were within the ranges reported for natural IPNV carriers (Billi \& Wolf 1969, Reno 1976). Both the prevalence of shedders and the IPNV titres in the feces fluctuated over time, similar to the situation observed in natural carriers (Billi \& Wolf 1969). Because these fluctuations occur, the lower prevalence of fecal shedders at 76 than at 27 wpi does not unequivocally indicate that the prevalence of fecal IPNV shedders decreases over time. Similariy, no definitive conclusion can be made about the difference observed in the prevalence of fecal shedders between the injected fish and the epizootic survivors, as the surviving yearlings were sampled only once, $73 \mathrm{wk}$ post-exposure.

As yearlings, natural IPNV carriers had a widespread distribution of IPNV in the visceral organs (Yamamoto 1974). In the present work, the injected yearlings also had a widespread distribution of IPNV in the visceral organs shortly after IPNV infection. Because the injected fish were viraemic for $12 \mathrm{wpi}$ (Bootland et al. 1986a), the virus could readily have spread to the visceral organs by the blood. Viraemia appears to play an important role in the early stages of IPNV infection of brook trout and rainbow trout (Swanson \& Gillespie 1982). The mean IPNV titres in the pyloric caecapancreas, liver, and intestine at $8 \mathrm{wpi}$ (Table 3) were within the ranges reported for yearling brook trout naturally-infected with IPNV (Reno 1976). However, the mean virus titres in the kidney, spleen, and gonad were $0.7,1.1$ and 1.1 logs lower, respectively, than the mean values reported for these organs in naturallyinfected brook trout (Reno 1976).

Infected fish tested at $76 \mathrm{wpi}$ had fewer IPNVinfected visceral organs per fish than did fish tested at $8 \mathrm{wpi}$. There was a lower prevalence of infection in all organs except the gonad, and IPNV titres for all organs except the gonad and spleen were lower than in fish at
8 wpi (Table 3). Except for the gonad and intestine, the prevalence and titre of IPNV in each organ were equivalent in the injected and surviving yearlings. For natural carriers of IPNV, there was a corresponding shift in the visceral distribution of IPNV over time, as the virus became primarily located in the pyloric caecapancreas and kidney (Reno 1976, Yamamoto \& Kilistoff 1979).

In contrast to the reports of decreased growth rates for wild IPNV carrier brook trout (Yamamoto 1975b) and cultured IPNV carrier rainbow trout (McKnight \& Roberts 1976), fish growth in this study was not affected by virus infection. The mean wet weights of the injected adults or the yearlings infected as fry were not significantly different from the control fish. The experimental conditions used in this study allowed much closer monitoring of growth rates of individual fish than in the previous studies. Thus, it appears possible to rear IPNV-infected fish in captivity that are not growthimpaired.

For routine detection of IPNV-carriers, this study has shown, in agreement with Billy \& Wolf (1969), that a single fecal sample per fish should not be relied upon to detect all fish carrying IPNV. Lethal organ sampling was more effective than a single fecal sample in identifying natural IPNV carrier fish (Frantsi \& Savan 1971), or, as shown in this study, experimentally-induced carriers. The best visceral organs to sample to detect natural IPNV varriers were the pyloric caeca-pancreas and the kidney, especially the posterior kidney (Yamamoto 1974, Mangunwiryo \& Agius 1988). These organs were also the most appropriate for detecting experimentally infected IPNV carriers. The intestine and gonad might also be useful samples, as these organs also had a high prevalence of IPNV infection. The spleen was of little value in detecting IPNV carriers as it had only a low prevalence of infection and low IPNV titre.

A strong humoral immune response against IPNV was mounted by yearling brook trout injected with a high dose of virulent virus (Fig. 3). This rapid production of IPNV-neutralizing antibodies in the first 3 mo post-injection has also been observed in rainbow trout injected with virulent virus (Wolf \& Quimby 1969) or inactivated virus in adjuvant (Sano et al. 1981). In addition, the peak antibody titres produced by the injected brook trout in this study were within the ranges reported for natural IPNV carrier rainbow trout (Agius et al. 1982, Mangunwiryo \& Agius 1988). Therefore, the time course and strength of the humoral immune response to IPNV appears to be the same for brook trout and rainbow trout.

The higher IPNV-neutralizing antibody titre at $76 \mathrm{wpi}$ in injected yearlings than that seen at $73 \mathrm{wk}$ post-exposure in the epizootic survivors may have been 
because the fry were exposed to a lower IPNV dose than the injected yearlings. Alternatively, exposure of the immunologically immature fry to IPNV may have induced a partial state of tolerance, thus rendering the fry incapable of producing as strong a humoral immune response as the injected yearlings, as suggested by Wolf \& Quimby (1969), Yamamoto (1975b) and Reno et al. (1978). This last possibility may explain why adult natural IPNV carrier brook trout produced lower antibody titres (Yamamoto 1975b, Reno 1976) than the injected yearlings in this study.

The observation that the mean antibody titre of the injected yearlings at 76 wpi was slightly higher than at 12 wpi could not be interpreted as indicating that the fish maintained a high antibody titre for over a year. Although not measured, the titres may have fluctuated between 12 and $76 \mathrm{wpi}$, similar to the seasonal fluctuations observed for rainbow trout IPNV carriers (Mangunwiryo \& Agius 1988).

The importance of the humoral immune response in IPNV infections is unclear. Antibodies may decrease virus spread via the blood, since there was an inverse relationship for the injected yearlings between viraemia (Bootland et al. 1986a) and antibody titres. However, the IPNV carrier state persisted in spite of high titres. Upon IPNV infection, the virus initiated a widespread infection of the visceral organs and, as suggested by Hedrick \& Fryer (1982), the virus may have become sequestered from antibody exposure before an adequate immune response could be mounted. To understand the mechanisms for the establishment and maintenance of IPNV infections it is essential that both the humoral and cellular immune responses to IPNV be studied.

In this study, it was not possible to predict which broodstock carriers would produce IPNV-infected progeny. Failure to detect IPNV in the reproductive products did not ensure that vertical transmission would not occur and, conversely, broodstock carriers with infected reproductive products did not always produce IPNV-infected progeny. These observations are relevant to IPNV diagnosis, as they indicate that sampling of only reproductive products, without lethal organ sampling, should not be used to identify IPNV carriers. It is strongly recommended that both the reproductive products and the visceral organs be sampled, even though the fish must be sacrificed. Even if the reproductive products of IPNV-carrier fish are IPNV-free, these fish should not be used for spawning purposes as the potential for vertical transmission of IPNV to progeny exists.

Although vertical transmission of IPNV from experimentally infected broodstock to progeny was demonstrated, this study made it apparent that there is a low probability of this being observed in laboratory studies.
Progeny fry had low mortality rates, low prevalence of IPNV-infection, and low virus titres, despite showing classical signs of IPN. Therefore, these fry parameters could not be reliably used to indicate that vertical transmission had occurred. The absence of IPNV in fry prior to the time of first feeding has also been noted by Ahne \& Negele (1985). This indicates that for IPNVdiagnosis, fry should not be considered as being IPNVfree if tested prior to the time of first feeding. Dorson \& Torchy (1985) were unable to demonstrate vertical transmission of IPNV from experimentally infected broodstock to progeny. These authors suggested that success may be a statistical problem when facilities are limited and only a small number of broodstock crosses can be made.

This study has shown that the occurrence of vertical transmission is unpredictable and has a low probability of being observed under laboratory conditions. Hence, monitoring for vertical transmission in broodstock IPNV immunization trials should not be used to evaluate vaccine efficacy. By characterizing the experimentally-induced IPNV carrier state, it was shown that intraperitoneal injection of virulent IPNV into yearling brook trout induced an IPNV carrier state nearly identical to that induced in fry by direct immersion and to the natural IPNV carrier state. Hence, intraperitoneal injection of virulent IPNV can be used as a challenge protocol to test the efficacy of IPNV vaccines for adult salmonids.

Acknowledgements. Support for this study was provided by awards from the Strategic Grants program of the Natural Sciences and Engineering Research Council of Canada. We thank the Ontario Ministry of Natural Resources for providing fish for some of the work.

\section{LITERATURE CITED}

Agius, C., Mangunwiryo, H., Johnson, R. H., Smail, D. A (1982). A more sensitive technique for isolating infectious pancreatic necrosis virus from asymptomatic carrier rainbow trout, Salmo gairdneri Richardson. J. Fish Dis. 5: 285-292

Ahne, W., Negele, R. D. (1985). Studies on the transmission of infectious pancreatic necrosis virus via eyed eggs and sexual products of salmonid fish. In: Ellis, A. E. (ed.) Fish and shellfish pathology. Academic Press, London, p. $261-269$

Ahne, W., Thomsen, I. (1986). Infectious pancreatic necrosis: detection of virus and antibodies in rainbow trout IPNVcarrier (Salmo gairdneri). J. Vet. Med. B. 33: 552-554

Billi, J. L., Wolf, K. (1969). Quantitative comparison of peritoneal washes and feces for detecting infectious pancreatic necrosis (IPN) virus in carrier brook trout. J. Fish Res. Bd Can. 26: 1459-1465

Bootland, L. M., Stevenson, R. M. W., Dobos, P. (1986a). Experimental induction of the carrier state in yearling brook trout: a model challenge protocol for IPNV immunization. Vet. Immunol. Immunopath. 12: 365-372 
Bootland, L. M., Stevenson, R. M. W., Dobos, P. (1986b). Silver nitrate pencils: a rapid marking technique for individual fish identification. AFS/FHS Newsletter 14: 6

Bullock, G. L., Rucker, R. R., Amend, D., Wolf, K., Stuckey, H. M. (1976). Infectious pancreatic necrosis: transmission with iodine-treated and nontreated eggs of brook trout (Salvelinus fontinalis). J. Fish. Res. Bd Can. 33: 1197-1198

Chang, N., MacDonald, R. D., Yamamoto, T (1978). Purification of infectious pancreatic necrosis (IPN) virus and comparison of polypeptide composition of different isolates. Can. J. Microbiol. 24: 19-27

Dobos, P., Hill, B. J., Hallett, R., Kells, D. T C., Becht, H., Teninges, D. (1979). Biophysical and biochemical characterization of five animal viruses with bisegmented RNA genomes. J. Virol. 32: 593-605

Dorson, M. (1982). Infectious pancreatic necrosis of salmonids. In: Anderson, D. P., Dorson, M., Dubourget, P. H. (eds.) Antigens of fish pathogens: development and production for vaccines and serodiagnostics. Collection Fondation Marcel Merieux, Lyon, p. 1-32

Dorson, M., Torchy, C. (1985). Experimental transmission of infectious pancreatic necrosis virus via the sexual products. In: Ellis, A. E. (ed.) Fish and shellfish pathology. Academic Press, London, p. 251-260

Frantsi, C., Savan, M. (1971). Infectious pancreatic necrosis virus: comparative frequencies of isolation from feces and organs of brook trout (Salvelinus fontinalis). J. Fish. Res. Bd Can. 28: 1064-1065

Hedric, R. P., Fryer, J. L. (1982). Persistent infections of salmonid cell lines with infectious pancreatic necrosis virus (IPNV): a model for the carrier state in trout. Fish Pathol. 16: $163-172$

Hill B. J. (1982). Infectious pancreatic necrosis virus and its virulence. In: Roberts, R. J. (ed.) Microbial diseases of fish. Academic Press, London, p. 91-114

Houston, A. H., DeWilde, M. A. (1969). Environmental temperature and the body fluid system of the fresh-water teleost - III. Hematology and blood volume of thermally acclimated brook trout, Salvelinus fontinalis. Comp. Biochem. Physiol. 28: 877-885

Kimura, T., Yoshimizu, M., Yasuda, H. (1984). Rapid, simple serological diagnosis of infectious pancreatic necrosis by coagglutination test using antibody-sensitized staphylococci. Fish Pathol. 19: 25-33

Mangunwiryo, H., Agius, C. (1988). Studies on the carrier state of infectious pancreatic necrosis virus infections in rainbow trout, Salmo gairdneri Richardson. J. Fish Dis. 11: $125-132$

Responsible Subject Editor: Dr T Evelyn, Nanaimo, B.C., Canada
McAllister, P. E., Owens, W. J. (1986). Infectious pancreatic necrosis virus: protocol for a standard challenge to brook trout. Trans. Am. Fish. Soc. 115: 466-470

McKnight, I. J., Roberts, R. J. (1976). The pathology of infectious pancreatic necrosis. I. The sequential histopathology of the naturally occurring condition. Br. vet. J. 132: 76-84

Reno, P. W (1976). Qualitative and quantitative aspects of the infectious pancreatic necrosis virus (IPNV) carrier state in trout. Ph. D. thesis, Univ. of Guelph

Reno, P. W., Darley, S., Savan, M. (1978). Infectious pancreatic necrosis: experimental induction of a carrier state in trout. J. Fish. Res. Bd Can. 35: 1451-1456

Sano, T., Tanaka, K., Fukuzaki, S. (1981). Immune response in adult trout against formalin killed concentrated IPNV Dev. Biol. Stand. 49: 63-70

Swanson, R. N. (1981). Use of the indirect fluorescent antibody test to study the pathogenesis of infectious pancreatic necrosis virus infection in trout. Dev. Biol. Stand. 49: 71-77

Swanson, R. N., Gillespie, J. H. (1982). Isolation of infectious pancreatic necrosis virus from blood and blood components of experimentally infected trout. Can. J. Fish. Aquat. Sci. 39: $225-228$

Wardlaw, A. C. (1985). Practical statistics for experimental biologists. John Wiley and Sons, Toronto

Wolf, K., Quimby, M. C. (1969). Infectious pancreatic necrosis: clinical and immune response of adult trouts to inoculation with live virus. J. Fish. Res. Bd Can. 26: 2511-2516

Wolf, K., Quimby, M. C. (1973). Fish viruses: buffers and methods for plaquing eight agents under normal atmosphere. Appl. Microbiol. 25: 659-664

Wolf, K., Quimby, M. C., Carlson, C. P., Bullock, G. L. (1968). Infectious pancreatic necrosis: selection of virus-free stock from a population of carrier trout. J. Fish. Res. Bd Can. 25: 383-391

Yamamoto, T. (1974). Infectious pancreatic necrosis virus occurrence at a hatchery in Alberta. J. Fish. Res. Bd Can. 31: $397-402$

Yamamoto, T. (1975a). Infectious pancreatic necrosis (IPN) virus carriers and antibody production in a population of rainbow trout (Salmo gairdneri). Can. J. Microbiol. 21: $1343-1347$

Yamamoto, T (1975b). Frequency of detection and survival of infectious pancreatic necrosis virus in a carrier population of brook trout (Salvelinus fontinalis) in a lake. J. Fish. Res. Bd Can. 32: 568-570

Yamamoto, T., Kilistoff, J. (1979). Infectious pancreatic necrosis virus: quantification of carriers in lake populations during a 6-year period. J. Fish. Res. Bd Can. 36: 562-567

Manuscript first received: August 17, 1989

Revised version accepted: September 26, 1990 